INFORMASI: Kajian Ilmu Komunikasi - ISSN (p) o126-0650; ISSN (e) 2502-3837

Vol. 48, No. 1 (2018), pp.79-93. doi: http://dx.doi.org/10.21831/informasi.v48i1. 17397

\title{
COUNTER HEGEMONI ATAS OTORITAS AGAMA PADA FILM (ANALISIS WACANA KRITIS FAIRCLOUGH PADA FILM SANG PENCERAH)
}

\author{
Syifaul Fauziyah \\ syifaziya@gmail.com \\ Kharisma Nasionalita \\ nasionalita.kharisma@gmail.com \\ Fakultas Komunikasi dan Bisnis, Universitas Telkom
}

\begin{abstract}
Religion became a tools to gain for gaining power through media. One of them is reflecting in a movie entitled Sang Pencerah. Through the Gramsci's theory, hegemony is an attempt to make the ruling elite dominate to lead the way of thinking, attitude, and assess the community to be in accordance with their will. Hegemony occur through mass media, education, preaching or dakwah. He also stated that the solution to oppose hegemony (counter hegemony) are focusing in education's field. This is very clear in the Sang Pencerah movie is shown how the Director create some discourse. This research aimed to find out the counter hegemony of Religious Authority in Sang Pencerah movie. Researchers used a qualitative approach, in which research is directed to inductive thinking by using Critical Discourse Analysis through microstructural (text), mesostructural (discourse), and macrostructural (sociocultural practices) steps. The subject of this study is the discourse of counter hegemony against the Religious Authority, while the object is the film Sang Pencerah. Researchers used a critical paradigm that is used to find out what is really going on behind the injustice or imbalance that exists. The result on micro phase, emphasis on the word "kafir", on meso, emphasis on counter (opposition Qiblat), and on macro emphasizes the institution's involvement, politics and discourse into media productions.
\end{abstract}

\begin{abstract}
Abstrak
Agama menjadi alat untuk mendapatkan kekuasaan melalui media. Salah satunya tercermin dalam film Sang Pencerah yang produksi oleh Hanung Bramantyo. Melalui teori Gramsci, hegemoni merupakan upaya untuk membuat pihak elit penguasa mendominansi untuk menggiring cara berpikir, bersikap, dan menilai masyarakat agar sesuai dengan kehendaknya. Hegemoni dapat terjadi melalui media massa, pendidikan, bahkan melalui dakwah kaum religius. Ia juga menyatakan, solusi untuk melawan hegemoni (counter hegemoni) dengan menitikberatkan pada sektor pendidikan. Hal ini terlihat denganjelas bagaimana counter hegemonidalamfilmSang Pencerah ditunjukkan kepada pembuat wacana. Penelitian ini dilakukan bertujuan untuk mengetahui counter
\end{abstract}


hegemoni terhadap Otoritas Agama dalam film Sang Pencerah. Peneliti menggunakan pendekatan kualitatif, yaitu penelitian yang diarahkan untuk berfikir induktif dengan menggunakan Analisis Wacana Kritis melalui tahap mikrostruktural (analisis teks), mesostruktural (praktik wacana), dan makrostruktural (praktik sosiokultural). Subjek dari penelitian ini yaitu wacana counter hegemoni terhadap Otoritas Agama. Sedangkan Objeknya adalah film Sang Pencerah. Peneliti menggunakan paradigma kritis yang digunakan untuk mencaritahu kebenaran yang sebenarnya terjadi, mencari tahu apa yang sebenarnya terjadi dibalik ketidakadilan atau ketidakseimbangan yang ada. Hasil penelitian pada tahap mikro menekankan pada kata "kafir", meso penekanan pada counter (pertentangan arah kiblat), dan makro menekankan pada keterlibatan institusi, politik, dan pembuat wacana masuk ke dalam produksi media.

Keywords: Muhammadiyah, Counter Hegemony, Religious Authority.

\section{PENDAHULUAN}

Budaya Populer masuk ke Indonesia salah satunya melalui film. Representasi masyarakat Indonesia, informasi, gambaran konflik negara atau hanya untuk hiburan semata diproduksi seorang sutradara untuk dikonsumsi oleh khalayak. Masyarakat tidak hanya dapat menikmatinya lewat suara tetapi masyarakat juga bisa langsung melihat gambaran cerita melalui bentuk visual. Pesan yang terkandung dalam cerita dapat diberikan secara langsung melalui film yang dilihat. Oleh karena itu film merupakan salah satu sarana untuk dapat membujuk atau mempersuasi akan suatu pesan yang ingin dituju oleh pembuat film kepada khalayak atau penonton.
Film di Indonesia khususnya film yang bergenre Islami mulai muncul setelah Orde Baru. Adanya film-film yang bertemakan Islam terus berkembang setiap tahunnya. Masyarakat pun juga semakin tertarik dan hal tersebut dapat membantu meningkatkan semangat pencipta karya film di Indonesia. Adapun daftar film yang bertemakan Islam beberapa tahun setelah Ayat-ayat Cinta keluar yaitu sebagaimana tabel 1.1.

Penduduk Indonesia yang mayoritas Islam dapat menjadi sasaran target dunia perfilman Indonesia. Islam sendiri sudah menjadi hal yang tidak asing bagi warga negara itu sendiri. Nilai-nilai Islam terus disebarkan melalui berbagai cara, salah satunya melalui film. Konten yang

Korespondensi: Syifaul Fauziyah. Universitas Telkom Bandung. Jalan Telekomunikasi No. 1, Deyeuh Kolot, Buah Batu, Kab. Bandung, 40267 Indonesia. Email: syifaziya@gmail.com

Tabel 1.1 Daftar Film Bertemakan Islam Tahun 2010

\begin{tabular}{ccc} 
& Sutradara & Tahun \\
Emak Ingin Naik Haji & Aditya Gumay & 2009 \\
\hline Perempuan Berkalung Sorban & Hanung Bramantyo & 2009 \\
\hline 3 Hati, Dua Dunia Satu Cinta & Benni Setyawan & 2010 \\
\hline Sang Pencerah & Hanung Bramantyo & 2010 \\
\hline Di Bawah Langit & Opick Gunung Nusa Pelita & 2010 \\
\hline Dalam Mihrab Cinta & Habiburrahman El Shirazy & 2010 \\
\hline Tanda Tanya & Hanung Bramantyo & 2011 \\
\hline Negeri 5 Menara & Affandi Abdul Rahman & 2012
\end{tabular}

Sumber: Olahan dari berbagai sumber 2017 
disampaikan pun juga mengandung unsur Islamisasi. Keadaan Islam pada masa Orde Lama ditandai dengan ideologi umat Islam yang masih kental. Disebut kental karena negara masih berusaha mencari identitas negara yang baru saja merdeka. Banyak partai Islam yang bermunculan seperti PNI (Partai Nasional Indonesia), PKI (Partai Komunis Indonesia), dan Masyumi (Majelis Syuro Muslimin Indonesia). Islam terus mendominasi dalam perjuangan dalam menemukan jati diri Indonesia.

Pada penelitian Heryanto (2015:40), Islamisasi merupakan sastu-satunya hal yang paling mencolok pada dekade pertama Indonesia sesudah Orde Baru (1966-1998). Selanjutnya pada tahun 2010 muncul Post Arab Spring atau Musim Semi Arab yang ditandai dengan banyaknya film Islamisasi yang ada seperti film Ayat-Ayat Cinta dan Ketika Cinta Bertasbih. Film-film tersebut memperlihatkan dengan jelas gambaran bagaimana sebenarnya Islam di dunia bagian barat merupakan panutan ajaran Islam sedunia. Selanjutnya di Era Baru yang ditandai dengan adanya modernitas dan religiuitas, hal ini menjadi jelas bagi umat Muslim di Indonesia bahwa keteganganketegangan yang menghadang mereka tak bisa disederhanakan menjadi modernitas sekuler yang berasal dari budaya Barat melawan tradisionalisme agama yang berasal dari belahan dunia lain. Hal ini ditandai dengan terbentuknya gugusan baru Muslim modern yang mulai di Indonesia (Heryanto, 2015:48).

Pada masa pasca Orde Baru, filmfilm yang bertemakan Islam banyak menceritakan kekuatan keimanan seorang Muslim dalam mempertahankan iman ditengah masyarakat yang beragam, baik terhadap orang Islam itu sendiri maupun dengan pemeluk agama lain. Salah satu contoh film yang menarik perhatian adalah film Sang Pencerah (2010, Bramantyo). Film yang menceritakan kehidupan dan perjuangan tokoh pahlawan Indonesia yaitu KH. Ahmad Dahlan. Film tersebut memperlihatkan bagaimana perjuangan sosok KH. Ahmad Dahlan bertahan dengan pendirian akan pemahamannya tentang agama Islam yang pada saat itu banyak ditentang oleh masyarakat yang ada disekitarnya hingga beliau dijuluki sebagai "Kyai Kafir" hanya karena perbedaan pemahaman serta pandangan agama Islam yang sebenar-benarnya. Perjuangan tersebut tidak berhenti disitu saja akan tetapi $\mathrm{KH}$. Ahmad Dahlan membentuk organisasi Islam bernama Muhammadiyah pada tahun 1912. Munculnya film Sang Pencerah ditujukan kepada anggota Muhammadiyah itu sendiri bersamaan dengan peringatan 100 tahun Muhammadiyah yang telah berkiprah di Indonesia.

Ideologi Muhammadiyah itu sendiri yaitu mengembalikan agama Islam yang sebenar-benarnya kepada Al-Quran dan Sunah. Pemilihan pemurnian atau purifikasi agama Islam menurut Nashir dalam buku Muhammadiyah Digugat (2000:8) adalah pemurnian agama yang memang seharusnya berkiblat kepada Al-Quran dan Sunah yang menjadi pedoman umat Islam sedunia dengan ijtihad atau bersungguh-sungguh. KH. Ahmad Dahlan merupakan sosok yang didambakan oleh Muhammadiyah karena beliau tidak membiarkan umat Islam dilanda kebodohan, kemiskinan, dan keterbelakangan maka dari itu diperlunya pengikisan melalui pendidikan sebagai gerakan budaya dengan mencerdaskan umat Islam, serta melakukan perlawanan total terhadap formalisme dan konservatisme agama, dengan cara mendobrak "TBC" (Takhayul, Bid'ah, Khurofat).

Organisasi Islam Muhammadiyah adalah sebuah organisasi Islam yang besar di Indonesia. Nama organisasi ini diambil dari nama Nabi Muhammad SAW, sehingga Muhammadiyah juga dapat diartikan dimana orang-orang yang menjadi pengikut Nabi Muhammad SAW. Tujuan utama Muhammadiyah adalah mengembalikan seluruh penyimpangan yang telah terjadi di tanah air dengan menggunakan proses dakwah. Penyimpangan ini sering menyebabkan ajaran Islam bercampurbaur dengan kebiasaan di daerah tertentu dengan alasan adaptasi. Muhammadiyah 
mempunyai gerakan dengan ciri-ciri semangat membangun tata sosial dan pendidikan masyarakat agar lebih maju dan berpendidikan. Ajaran Islam bukan sekadar agama yang bersifat pribadi dan statis, tetapi juga dinamis, bergerak, berkembang serta berkedudukan sebagai sistem kehidupan manusia dalam segala aspeknya.

Penulis memilih film Sang Pencerah karena dilihat cerita, konflik dan pesan yang disampaikan oleh sutradara begitu jelas sangat mencerminkan hiruk-pikuk keadaan Islam di Indonesia pada saat itu terutama dalam hal keyakinan KH. Ahmad Dahlan yang mempunyai pemaham serta pandangan Islam yang berbeda. Selain itu sutradara juga menunjukkan bahwa adanya beberapa counter yaitu counter hegemoni yang dilakukan oleh KH. Ahmad Dahlan serta film karya Hanung ini termasuk dikategorikan berani dalam mengangkat beberapa point yang bisa menimbulkan kontroversi diantara umat beragama. Awal adanya counter tersebut dalam film Sang Pencerah dijelaskan bahwa saat itu Islam terpengaruh ajaran Syeh Siti Jenar yang meletakkan raja sebagai perwujudan Tuhan. Masyarakat meyakini titah raja adalah sabda Tuhan syariat Islam bergeser kearah tahayul dan mistik. Sementara itu kemiskinan dan kebodohan merajalela akibat politik tanam paksa pemerintah Belanda dan agama tidak bisa mengatasi keadaan, terlalu sibuk dengan tahayul yang bertentangam dengan Al Quran dan Sunah Rasul Muhammad SAW.

Perjuangan dan munculnya counter hegemoni dimulai ketika KH. Ahmad Dahlan menunaikan ibadah Haji, di kota yang penuh diberkahi beliau banyak belajar serta mendalami Islam dengan sebenar-benarnya. Setelah pulang dari tanah suci, KH. Ahmad Dahlan mulai mengamati lingkungan dimana ia berada, yaitu di wilayah Kauman Yogyakarta. Banyak sekali yang janggal dan terdapat kesalahpahaman yang selama ini masyarakat Islam lakukan.

Dalam jurnal kajian informasi Sardiman (2000), pandangan yang agak berbeda tentang Islam di Jawa dikemukakan oleh Benda, yang menyatakan bahwa di sebagian besar Pulau Jawa, Islam dipaksa untuk menyesuaikan diri dengan tradisi-tradisi yang telah berabad-abad umurnya, sebagian tradisi penduduk asli, sebagian tradisi Hindu-Budha, dan dalam prosesnya banyak kehilangan kekakutan doktrinernya. Dan memang Islam Jawa dalam waktu yang cukup panjang lebih penting dalam arti politik daripada religius. Sekurang-kurangnya pada mulanya dia tidak menimbulkan perubahan yang radikal dalam kehidupan agama dan sosial di Pulau Jawa.

Sehingga tidak heran jika banyak masyarakat muslim yang beragama Islam namun tetap sangat mempercayai dengan hal-hal yang berbau takhayul dan mistik dengan melakukan banyak tradisi-tradisi. Dari situ, KH. Ahmad Dahlan mulai menanamkan pemahaman beliau tentang agama Islam yang cenderung lebih sederhana dan tidak memberatkan bagi Umat Islam itu sendiri. Pemahaman dan dakwah yang disebarkannya berdasarkan Al-Quran dan Sunah dimana semua yang dilakukan oleh umat Islam sebenarnya harus dilandaskan dengan dua hal tersebut. Tetapi dengan ideologi seperti itu tidak mudah untuk masuk kedalam pemahaman masyarakat bahkan sangat bertolak belakang dimana pada masa itu di daerah Kauman sendiri masih sangat kental dengan adat dan budaya yang dicampur-adukkan atau dikaitkan dengan pelaksanaan dalam menjalankan ibadah kepada Allah.

Pada tahun 2010, banyak yang terjadi di Indonesia yang berkaitan dengan film Sang Pencerah. Terdapat tiga fokus yaitu:

Pertama, tentang "Polemik Pergeseran Arah Kiblat”. Dalam berita bbc.com, yang membahas mengenai arah kiblat, pada saat itu Indonesia dihadapkan dengan kebingungan yang terjadi karena fatwa MUI mengenai arah kiblat yang benar. Padahal sebenarnya sudah 100 tahun yang lalu dijelaskan kepada KH. Ahmad Dahlan tentang kebenaran arah kiblat dan hal ini dijelaskan kembali dengan cara yang halus dalam film Sang Pencerah. (http://www.bbc.com/indonesia/berita_ indonesia/2010/07/100720_kabah,diakses pada 11 September 2017, 18.30 WIB) 
Kedua, tentang "Kekerasan atas Nama Agama”. Dalam berita bbc.com, keadaan Indonesia pada saat itu dihadapkan dengan keadaan kontemporer khususnya pasca jaman Soeharto. Masyarakat beragama tidak saling memberikan toleransi, baik sesama umat Muslim maupun yang berbeda agama. Hanya karena beda pemahaman kelompok satu dengan kelompok lain, pertaruhan dan konflik banyak terjadi. Hal ini digambarkan dalam film Sang Pencerah ketika langgar KH. Ahmad Dahlan dihancurkan dengan umat sesama Muslim yang menjadi penggiat di Masjid Gede hanya karena perbedaan pemahaman. (http://www.bbc.com/ indonesia/laporan_khusus/2012/o7/120702_ peran_negara_toleransi, diakses pada 11 Januari 2017, pukul 18.40 WIB)

Ketiga, "Dunia Pendidikan”. Dalam berita news.detik, banyak sekali kasus kekerasan anak yang dilakukan oleh guru tak kunjung henti. Mulai dari pelecehan seksual hingga kekerasan kepada Murid. Menurut Komisi Nasional Anak, pada tahun 2010 terdapat 1.234 pengaduan. Sedangkan menurut detik.com, KPAI menjelaskan bahwa jenis kekerasan yang paling banyak terjadi kepada anak adalah kekerasan seksual sebanyak 45,7 persen sebanyak 53 kasus, kekerasan fisik sebanyak 25 persen sebanyak 29 kasus, penelantaran sebanyak 20,7 persen sebanyak 24 kasus, dan kekerasan psikis 8,6 persen sebanyak 10 kasus. Hal ini diceritakan tentang bagaimana perjuangan $\mathrm{KH}$. Ahmad Dahlan dalam mengayomi anak dalam hal pendidikan seperti beliau mempunyai cara yang sederhana dalam mengajarkan suatu ilmu kepada muridnya. (http://www.bbc. com/indonesia/majalah/2010/o1/100121_ streetkids_storyana, diakses pada 12 Januari 2018, pukul 15.12 WIB)

Metode atau cara KH. Ahmad Dahlan dalam mengajak dan membuka pikiran masyarakat dan tidak serta merta memaksa pendapat atau pemahamannya harus bisa diterima oleh masyarakat tetapi cara beliau bertahap, halus dan tidak terkesan memaksa. Ajaran yang disebarkan melalui pendidikan dan terjun langsung kedalam masyarakat untuk mempraktekkan kandungan- kandungan yang ada di dalam butiranbutiran ayat suci Al-Quran. Sehingga dari film Sang pencerah ini dapat dilihat KH. Ahmad Dahlan yang menggunakan cara counter hegemoni yaitu ketika beliau mengajak masyarakat Indonesia khususnya yang berada di daerah Kauman untuk mengubah pandangan akan agama Islam serta bagi umat Islam sendiri memahami Islam dengan sebenar-benarnya menurut Al-Quran dan Sunah Nabi Muhammad SAW melalui purifikasi Islam. Purifikasi atau pemurnian ini bertujuan untuk memaknai ajaran Islam sebelum adanya tambahan tradisi dan ritualritual yang sudah turun-temurun dilakukan oleh masyarakat Islam sendiri.

Dalam Ilmu Komunikasi khususnya di kajian Cultural Studies kita mengenal istilah counter hegemoni yang berarti menolak adanya hegemoni. Menurut Gramsci dalam teorinya, ia memberi solusi untuk melawan hegemoni (Counter hegemoni) yaitu dengan menitikberatkan pada sektor pendidikan. Adanya counter hegemoni muncul karena adanya hegemoni. Hegemoni sendiri adalah upaya atau carayang dilakukan agar membuat suatu kelompok terpengaruh atau mengikuti cara-cara berpikir kelompok tertentu dengan cara memberikan pemahaman yang dianggap benar sehingga kelompok yang terhegemoni menganggap bahwa pemahaman yang diberikan kelompok itu benar saja dan sahsah saja diterapkan. Padahal tanpa disadari mereka sudah terhegemoni oleh kelompokkelompok tertentu yang memiliki suatu kepentingan. Hegemoni dilakukan secara terus menerus. Perjuangan hegemoni pun juga berlangsung secara luas yaitu mencakup masyarakat sipil (pendidikan, serikat pekerja, keluarga) (Fairclough, 2010:61).

$$
\text { Pada penelitian ini, peneliti }
$$
menggunakan metode Analisis Wacana Kritis Fairclough. Dalam metode tersebut akan ada tiga hal yang akan dikaji yaitu mikrostruktural (teks), mesostruktural (praktik wacana) dan makrostruktural (praktik sosio kultural). "Analisis ini yang tidak hanya menganalisis wacana tetapi juga menganalisis hubungan antara wacana dengan objek atau elemen dari proses sosial" 
(Fairclough, 1989:19).

Tujuan dari penelitian ini untuk mengetahui Mikrostruktural, Mesostruktural, dan Makrstruktural Counter Hegemoni dalam Film Sang Pencerah. Diharapkan dengan penelitian ini dapat bermanfaat untuk menambah literatur dalam dunia ilmu komunikasi khususnya tentang penelitian Analisis Wacana Kritis Fairclough, menambah wawasan serta pengetahuan peneliti serta masyarakat tentang adanya counter hegemoni dalam film Sang Pencerah, menjadikan sumber pengetahuan penulis tentang adanya counter hegemoni dalam film Sang Pencerah, menjadikan sumber masukan bagi peneliti lain yang akan meneliti tentang Analisis Wacana Kritis dalam Film.

\section{METODE}

Penelitian ini menggunakan pendekatan kualitatif. Analisis data kualitatif menurut Bognan \& Biklen (1982), sebagaimana dikutip Moleong (2007:248), adalah upaya yang dilakukan dengan jalan bekerja dengan data, mengorganisasikan data, memilah-milahnya menjadi satuan yang dapat dikelola, men-sintesiskannya, mencari dan menemukan pola, menemukan apa yang penting dan apa yang dipelajari, dan memutuskan apa yang dapat diceritakan kepada orang lain. Berdasarkan definisi di atas dapat disimpulkan bahwa langkah awal dari analisis data adalah mengumpulkan data yang ada, menyusun secara sistematis, kemudian mempresentasikan hasil penelitiannya kepada orang lain.

Paradigma Kritis merupakan proses untuk menemukan sesuatu hal yang sebenarnya terjadi dalam pandangan peneliti itu sendiri, observasi atau pengalaman tidaklah jelas dengan sendirinya. Menurut Teori yang dikembangkan oleh mazhab Frankfurt. Paradigma Kritis mendefinisikan fenomena sosial sebagai suatu proses yang secara kritis berusaha mengungkap the real structure dibalik ilusi, yang dinampakkan dunia materi, dengan tujuan membantu membentuk suatu kesadaran sosial agar memperbaiki dan merubah kondisi kehidupan manusia.
Analisis teori kritis tidak memusatkan pada kebenaran dan ketidakbenaran struktur tata bahasa atau proses penafsiran seperti konstruktivisme, namun analisis kritis menekankan pada produksi dari sebuah makna. Sehingga peneliti menggunakan paradigma kritis untuk meneliti tentang "Analisis Wacana Kritis Counter Hegemoni dalam Film Sang Pencerah"

Subjek penelitian adalah subjek yang dituju untuk diteliti oleh peneliti. Subjek atau bisa disebut dengan informan penelitian merupakan subjekyang memahami rumusan masalah penelitian. (Burhan, 2007: 78) Dalam penelitian ini yang menjadi subjek penelitian adalah wacana counter hegemoni terhadap Otoritas Agama. Objek penelitian adalah objek yang dijadikan penelitian atau yang menjadi titik perhatian suatu penelitian (Burhan, 2007: 78). Pada penelitian ini objek yang digunakan adalah Film Sang Pencerah karya Hanung Bramantyo yang dikeluarkan pada tahun 2010.

Dalam penelitian, unit analisis yang akan digunakan yaitu potongan beberapa scene dalam Film Sang Pencerah. Film yang berdurasi 02:00:34 akan diambil beberapa bagian yang mengandung counter hegemoni yang selanjutnya akan dianalisis oleh peneliti menggunakan Analisis Wacana Kritis Fairclough. Transliterasi teks dialog pada teks digunakan untuk menganalisis mikrostruktral, mesostruktural menggunakan analisis dokumen pada video behind the scene film Sang Pencerah dengan memilih part dimana sang sutradara mengemukakan pendapatnya terkait dengan film. Selain itu untuk mendukung analisis peneliti, bagian yang diambil tidak hanya dari pendapat sutradara saja, tetapi juga dari pemain utama yang lain. Dari berbagai sudut pandang tersebut cukup mewakili untuk bisa menggabungkan analisis teks dan praktik sosiokultural. Sedangkan untuk makrostruktural menggunakan studi pustaka, wawancara informan pendukung serta penulusuran sejarah.

Dijelaskan oleh Sugiyono (2009:225), bahwa pengumpulan data dapat diperoleh dari hasil observasi, wawancara, 
dokumentasi, dan gabungan atau triangulasi. Pada penelitian ini peneliti menggunakan teknik pengumpulan data dengan cara observasi, wawancara, metode dokumentasi dan studi pustaka.

\section{HASIL DAN PEMBAHASAN}

Fairclough menganalisis wacana kritis dengan tiga bagian, yaitu analisis teks, praktik wacana, dan praktik sosiokultural. Pada tahap Mikrostruktural, peneliti

Tabel 1.2 Pengumpulan Data Penelitian dan Metode Fairclough

\begin{tabular}{|c|c|c|}
\hline Struktur & Metode & Data \\
\hline Mikrostuktural (Teks) & $\begin{array}{l}\text { Transliterasi dialog dalam } \\
\text { beberapa scene yang ada pada: } \\
\text { 1. }(00: 17: 03)-(00: 18: 05) \\
\text { 2. }(00: 27: 57)-(00: 31: 00) \\
\text { 3. }(01: 01: 00)-(01: 02: 25) \\
\text { 4. }(01: 02: 55)-(01: 06: 30) \\
\text { 5. }(01: 21: 15)-(01: 23: 54) \\
\text { 6. }(01: 24: 30)-(01: 27: 00) \\
\text { 7. }(01: 38: 21)-(01: 40: 28) \\
\text { 8. }(01: 43: 00)-(01: 45: 05) \\
\text { 9. }(01: 49: 10)-(01: 53: 45)\end{array}$ & $\begin{array}{l}\text { Teks dialog film } \\
\text { Sang Pencerah }\end{array}$ \\
\hline $\begin{array}{c}\text { Mesostruktural (Praktik } \\
\text { Wacana) }\end{array}$ & Analisis Dokumen & $\begin{array}{l}\text { Rekaman Video } \\
\text { wawancara } \\
\text { behind the } \\
\text { scene Hanung } \\
\text { Bramantyo } \\
\text { (Sutradara, } \\
\text { Produser, } \\
\text { Skriptwiter) dan } \\
\text { beberapa pemain } \\
\text { yang terlibat }\end{array}$ \\
\hline $\begin{array}{l}\text { Makrostruktural (Praktik } \\
\text { Sosiokultural) }\end{array}$ & $\begin{array}{l}\text { Studi pustaka,wawancara, dan } \\
\text { penelusuran sejarah }\end{array}$ & $\begin{array}{c}\text { Data wawancara: } \\
\text { Informan } \\
\text { pendukung }\end{array}$ \\
\hline
\end{tabular}

Sumber: Data Olahan Peneliti 2017

mengkategorikan dalam proses analisis teks ini menjadi lima bagian yaitu Tauhid, Fiqih, Toleransi, Dakwah, dan Counter atau tandingan. Tauhid merupakan suatu pengakuan atas keesaan Allah SWT bahwa Tuhanitu satu, Allah. Dalam beribadah tujuan utama umat Islam adalah untuk mendapat ridhoNya. Ibadah hanya ditujukan kepada yang satu tetapi pada kenyataanya masih banyak yang melenceng dari itu. Dalam analisis teks diatas banyak memperlihatkan bahwa patuh dan taat kepada apa yang dikatakan dan diperintahkan oleh Otoritas
Agama. Begitupun dengan berdo'a, yang dituju bukan kepada Tuhan tetapi kepada pohon dengan menggunakan sesaji. Fiqih merupakan sebuah ilmu yang mempelajari tatanan atau aturan untuk mengatur seluruh aspek kehidupan manusia, mulai dari bermasyarakat hingga menjalankan kehidupan sehari-hari serta Ibadah. Tatanan dan aturan yang sudah dipelajari umat Islam ada dasarnya dan semua sudah tercantum pada Al-Qur'an tetapi setiap manusia mempunyai prespektif yang berbeda dalam memandang suatu aturan. Bahasa Al-Qur'an 
dapat diartikan kedalam beberapa versi sehingga tidak heran jika muncul mazhabmazhab yang dianut oleh umat agama Islam. Toleransi merupakan suatu sikap menghargai perbedaan yang ada dalam lingkungan seperti halnya Indonesia yang mempunyai banyak suku dan adat tetapi dalam sebuah keragaman tetap bisa bersatu jika adanya toleransi. Dakwah merupakan sebuah penyampaian informasi atau pesan yang positif kepada umat manusia. Istilah dakwah biasanya digunakan oleh orang Islam dalam penyebaran ajaran agama Islam di dunia. Counter atau Tandingan adalah sebuah kontra yang muncul akibat adanya sebuah kondisi yang dominan. Tandingan bisa dikatakan sebuah kritik terhadap hal yang mendominansi di lingkungan tersebut.

Dari keseluruhan hasil analisis teks, dapat diketahui bahwa dari teks dialog film bahwa unsur counter hegemoni selalu muncul pada setiap analisis teks. Selalu ada tadingan ideologi atau pemahaman dari KH. Ahmad Dahlan terhadap lingkungannya. Counter hegemoni muncul karena adanya hegemoni yangada. Jika dihubungkan dengan hegemoni Gramsci, ia pernah mengatakan bahwa ada beberapa cara yang dipakai untuk melakukan hegemoni, misalnya melalui institusi yang ada di masyarakat yang menentukan secara langsung atau tidak langsung strukturstruktur kognitif dari masyarakat. Dalam hal ini, wujud counter hegemoni KH. Ahmad Dahlan melalui institusi yaitu sekolah yang didirikan oleh beliau di rumahnya.

Dari hasil analisis mesostruktural (praktik wacana), ada beberapa point yang menjadi fokus pembahasan yaitu tentang kiblat, kafir, dan counter hegemoni. Kiblat merupakan masalah yang besar dalam teks dialog karena selama ini umat Islam menjalankan ibadahnya selalu mengarah kepada kiblat, tetapi ternyata ada yang menentang bahwa kiblat yang dianut selama bertahun-tahun salah menurut ukuran ilmu falak dan dari tinjauan letak geografis. Sehingga orang yang menentang dan ingin meluruskan akhirnya dikatakan sebagai orang yang kafir karena mengikuti paham yang diajarkan oleh orang kafir.
Paham yang dianggap benar di lingkungan adalah paham yang sudah turun-temurun dipercaya dan diamalkan sesuai dengan perintah Pemuka Agama atau Otoritas Agama. Otoritas mempunyai porsi yang besar dalam peranannya untuk mengatur umat. Muncul lebel yang dikeluarkan oleh Otoritas Agama yaitu lebel kafir. Lebel yang menentang ajaran yang selama ini diajarkan dan mempunyai pemahaman dan pemikiran tersendiri tentang agama Islam.

Dari hasil makrostruktural (praktik sosiokultural), peneliti membaginya menjadi 3 (tiga) level yaitu situasional, institusional, dan sosial. Pada situasional peneliti membahas tentang faktor terbentuknya film menurut persepsi pembuat wacana dan dari pandangan anggota organisasi Muhammadiyah. Selain itu kondisi yang mendukung terbentuknya wacana karena adanya pergeseran makna Islam di lingkungan Kauman dan konflik-konflik toleransi yang terjadi baik antar agama maupun dengan agama Islam itu sendiri. Kedua, institusional peneliti membahas tentang dari segi pendidikan, Budi Utomo, faktor ideologi pembuat wacana yang masuk ke dalam film, dan keterlibatan Keraton. Yang terakhir, sosial, membahas tentang adanya dominansi, masyarakat yang cenderung masih tradisional, keterlibatan media dan politik yang dikemas ke dalam bentuk media yaitu film.

Teks dialog pada film Sang Pencerah menjelaskan bahwa adanya pertentangan yang besar dari orang terdekat KH. Ahmad Dahlan sendiri yaitu keluarga. Disaat orang terdekatpun tidak mempercayai dan mendukung KH. Ahmad Dahlan tetapi tidak menyurutkan beliau untuk meneruskan keyakinannya dan tetap terus berdakwah di jalan Allah. Semua orang memiliki ketakutan tersendiri jika terlihat beda dengan orang lain. Maka lebih baik mencari aman dan tetap mengikuti aturan yang berlaku. Tetapi aturan yang berlaku dan sudah dipercaya turun-temurun masih bisa diterapkan seiring berkembangnya zaman atau tidak. Sehingga muncul mazhab-mazhab yang berbeda-beda untuk bisa digunakan umat Islam dalam 
menjalankan dan membantu keyakinannya dalam beribadah. Mazhab adalah sesuatu ciri atau jalan yang dilalui seseorang untuk menjadi tujuan yang konkrit atau abstrak.

Di Indonesia mengenal istilah Bhineka Tunggal Ika, agama Islam mengenal Agama dengan arti merohmati, melindungi siapapun yang bernaung dibawahnya, baik Islam maupun bukan Islam. Sehingga perlu adanya toleransi dan pelurusan dalam memaknai sebuah agama. Bukan berarti jika beda bisa dihancurkan tetapi dihormati. Kekuasaan yang mempunyai porsi terbesar dalam mengontrol struktur sosial yang menjadi panutan masyarakat.

Islamisasi dan Budaya Populer datang hingga masuk ke negara Indonesia melalui berbagaicara,salahsatunyadalambentukfilmfilm Islami yang menjadi konsumsi publik. Hingga muncul film Sang Pencerah karya Hanung yang menceritakan tentang tokoh pendiri organisasi Islam, Muhammadiyah. Di dalam buku Muhammadiyah digugat (200o), bahwa Muhammadiyah didirikan sebagai fenomena baru dari wajah Islam abad ke-20. Kembali kepada Al-Quran dan Sunah bukan dipandang hanya sebagai purifikasi saja. Tetapi lebih kepada sikap skripturalistik Muhammadiyah, yang dalam waktu sama kehilangan daya hadapnya terhadap realitas kontekstual modernitas. Berdiri dengan 2 tujuan utama yaitu melepaskan umat Islam dari lingkungan TBC (Takhayul, Bid'ah dan Khurafat) yang membelenggu umat dari pemahaman yang benar tentang tauhid yang benar. Selanjutnya, memajukan pendidikan umat Islam yang memberikan angkatan mudanya ilmu-ilmu Barat dalam rangka merebut kebahagiaan keduniaan yang juga harus dikejar oleh umat Islam. Muhammadiyah merupakan gerakan organisasi yang menggunakan strategi tajdid. Tajdid adalah suatu pemahaman nilai-nilai Islamiyang memang tidak boleh "digadaikan" dan tidak boleh dikompromikan dengan nilai-nilai non-Islami, tetapi tidak boleh bersikap apriori terhadap apa yang datang dari luar Islam, kalau memang hal-hal yang dari luar datang itu positif akan diterapkan tetapi jika tidak maka tidak akan diterapkan oleh Muhammadiyah. Muhammadiyah tidak begitu gampangnya membawa modernisme hingga meninggalkan hal yang utama pada nilai-nilai Islam. Telah dijelaskan pula oleh informan dalam penelitian ini bahwa Muhammadiyah termasuk "ummatan washato", umat yang ditengah-tengah.

Muhammadiyah dalam menyebarkan paham atau pemikirannya melalui dakwah. Pengertian dakwah sendiri adalah mengajak seseorang atau kelompok untuk memeluk agama Islam demi kebaikan mereka di dunia dan keselamatan di akhirat kelak serta mencari rahmat dari Allah SWT. Perbedaan sebelum dan sesudah adanya dakwah bisa dicontohkan kalau dahulu masih banyak umat Islam yang syirik (penyekutukkan Allah), menyembah Tuhan selain Allah. Tetapi setelah adanya dakwah, umat Islam mulai memiliki kesadaran akan ketauhidan, yaitu menyembah hanya kepada satu, Allah.

Sejarah berdirinya Muhammadiyah dengan tujuan awal merujuk kepada surat Ali-Imran ayat 104 dan Al-Ma'un yang intinya beramal ma'ruf nahi mungkar artinya mengajak kebaikan dan mencegah hal yang mungkar. Muhammadiyah dalam dakwahnya menyatakan bahwa mereka termasuk golongan umat Muslim yang berada di tengah-tengah, tidak terlalu kanan dan tidak terlalu kiri. Muhammadiyah menyebutnya dengan "ummatan wasahto" yang sudah tertulis di dalam Al-Quran yaitu surat Al Baqoroh ayat 143. Ada beberapa masyarakat yang menyebut Muhammadiyah sebagai Islam yang moderat. Moderat dalam arti menerima perubahan dan bahkan dapat menerima apapun yang berasal dari nonIslam. Muhammadiyah tidak selemah itu untuk menerima pemahaman dan aliran yang baru atau modern.

Informan mengatakan dalam wawancara dengan peneliti bahwa agama Islam haruslah berkemajuan sehingga jangan sampai umat Islam menjadi masyarakat yang tertinggal dan dipandang terbelakang, sedangkan terbelakang sendiri bukan merupakan watak Islam. Maka dari itu perlunya dilakukan perubahan Budaya. Tradisional berasal dari 
kata dasar tradisi yang berarti adat, dimana adat sendiri menurut masyarakat Jawa harus dilestarikan dan dipertahankan. Tetapi bukan berarti ajaran dan tradisi tersebut dicampur-adukkan dengan pelaksanakan ibadah dalam agama Islam.

Dari wawancara diatas dapat kita lihat bahwa informan sebagai Pimpinan Pusat Muhammadiyah yang sekarang mewakili masyarakat dalam organisasi Muhammadiyah mengungkapkan dengan jelas tandingan atau memberikan pandangan yang kontra terhadap masyarakat tradisional yang tidak bisa menerima hal yang baru dan pemikiran modern yang mengikuti jaman. Dalam hal ini Muhammadiyah menjadi posisi yang memiliki pemikiran modern yang mengutamakan pemurnian agama Islam yang dihadapkan dengan masyarakat yang masih tradisional yang masih menganut paham yang turun temurun yang berlangsung selama ini. Informan dari organisasi Muhammadiyah, yang juga merupakan informan memiliki pendapat dalam memahami makna masyarakat Tradisional. Masyarakat tersebut hanya mengandalkan taklid yang artinya mengikuti saja tanpa memahami dasar-dasarnya. Serta tidak memahami Islam secara kaffah, yaitu secara sempurna.

Penelitian ini bertujuan untuk menemukan dan mengetahui dimana letak counter hegemoni dalam sebuah wacana. Jika dilihat dari mikrostruktural dan mesostruktural peneliti mengindikasi bahwa film Sang Pencerah meng-counter Otoritas Agama. Tetapi peneliti menemukan sesuatu hal yang baru lagi dari wawancara yang diperoleh dari Informan dari organisasi Muhammadiyah yang membahas tentang Otoritas Agama. Menurutnya Otoritas yang ada di Indonesia ini mulai terpecah dengan sendirinya dan terbagi menjadi dua. Biasa disebut dengan BanSer (Barisan Serbaguna) merah dan BanSer putih. Barisan Serbaguna adalah milik Ansor, yang merupakan organisasi naungan NU (Nadhatul Ulama).

Di dalam Barisan Serbaguna sendiri ada salah satu yang disusupi oleh orangorang PKI. Masyarakat Indonesia sudah mengatahui bahwa PKI (Partai Komunis Indonesia) merupakan kelompok yang berbahaya karena telah meninggalkan bekas luka yang mendalam kepada negara Indonesia. Sehingga dalam hal ini, jika dihubungkan dengan kejadian-kejadian sekarang di dalam Otoritas Agama itu sendiri sudah terpecah belah.

Menurut Pintak dalam jurnal kajian komunikasi Herawati (2016), mengatakan bahwa nilai dan tradisi etnis memengaruhi perspektif Muslim di Indonesia terhadap hukum Islam. Melihat pada akar pemikiran keislaman bangsa Indonesia, kita mengenal dua organisasi besar yang memiliki pengikut terbanyakyaitu Muhammdiyah dan Nadhatul Ulama (NU). Muhammadiyah mengambil sikap tegas dengan menerjemahkan Islam secara moderat dan terpengaruh pendidikan Barat, mereka tidak menjadikan kyai atau pimpinan agama seolah-olah kultus dan memiliki kuasa yang sangat kuat. Sedangkan Nadhatul Ulama (NU), secara sejarah diketahuimengambilperansebagaiorganisasi Islam yang melakukan penerjemahan hukum Islam atau menggabungkannya kedalam nilai-nilai tradisional. Pimpinan agama yang mereka sebut kyai sangat dikultuskan dan bukan orang yang dapat mereka pertanyakan pendapatnya.

Kejadian atau konflik-konflik yang terjadi di Indonesia mengenai hal agama banyak sekali dan ini menyangkut dengan toleransi. Dalam film Sang Pencerah sendiri diperlihatkan bahwa adanya konflikkonflik karena kurang adanya toleransi dengan sesama umat Islam sendiri, hingga menimbulkan tindakan yang ekstrem yaitu merobohkan langgar. Padahal negara Indonesia sendiri menegakkan Bhineka Tunggal Ika, meskipun berbeda tetapi masih tetap satu dan dapat berjalan berdampingan. Bagaimana rakyat mempertahankan ketoleransian ini. Hal ini merupakan suatu yang fundamental. Perekat keberagaman yang ada di Indonesia ini adalah Islam. Tanpa Islam, akan lebih sulit berdiri di negara yang sangat beragam sekali kebudayaan, suku, ras dan Agama. Kekacauan ini mulai terlihat di teks dialog film pada saat membongkar 
langgar milik KH. Ahmad Dahlan yang telah diungkapkan pada wawancara dengan Informan dari organisasi Muhammadiyah.

Padatahun-tahunsejarahituberlangsung dalam arti saat KH. Ahmad Dahlan berjuang dengan organisasi Muhammadiyahnya masih belum banyak kepentingan politik. Ada, tetapi tidak begitu terlihat dan pada saat 1912 saat Muhammadiyah berdiri, Indonesia belum merdeka. Pemerintahan yang memiliki kuasa hanya Keraton dan Pemuka Agama yang mempunyai kontrol yang lebih kepada masyarakat. Pada film Sang Pencerah, Keraton tidak memihak kepada siapa yang lebih dominan, tetapi lebih kepada mendukung masyarakat yang dapat membantu dalam kemajuan pendidikan modern. Kedudukan KH. Ahmad Dahlan dalam teks dialog bukan seseorang yang mempunyai kekuatan, dominansi atau power yang bisa mengarahkan masyarakat sejalan dengan pemikirannya. Tetapi sebaliknya, beliau merupakan orang yang dianggap miring dan sinting pada saat itu, dalam wawancara Hanung Bramantyo di acara Mata Najwa.

Keraton turut andil dalam mendukung pemikiran KH. Ahmad Dahlan dengan membiayai pemberangkatan beliau ke Mekkah untuk memperdalam lagi pemahaman tentang agama Islam. Niat yang baik untuk memajukan masyarakat Islam agar tidak terbelakang sangat terlihat dalam teks tersebut. Peneliti menganalisis bahwa adanya pesan yang dibawa Hanung ke dalam film bahwa pemerintah sangat mendukung adanya kemajuan. Berbeda dengan yang ada sekarang di Indonesia. Siapa yang dominan, siapa yang menang dalam lingkaran partai maka dia yang akan terlihat. Kekuasaan tidak lepas dari permainan politik. Politik juga tidak bisa terlepas dari agama. Karena dasardasar aturan yang dijadikan sebuah pondasi peraturan politik di Indonesia. Agama bisa mengarahkan berjalannya sebuah politik. Sehingga dengan begitu politik memberikan peluang bagi Agama. Di dalam agama terdapat pemuka-pemuka agama yang kita sebut Otoritas Agama. Dalam politik, tidak mengenal mana yang lebih baik dan bermanfaat untuk masyarakat luas. Tetapi lebih mementingkan siapa yang menang dalam pemilihan sehingga hanya melihat yang memenangkan kekuasaan dan bersifat dominan ditengah-tengah masyarakat. Seperti yang dikatakan oleh informan dari segi pengamat politik dalam wawancaranya, bahwa terdapat peluang yang besar jika Otoritas Agama tersebut menduduki posisi di bangku DPR. Karena DPR merupakan pusat menampungnya aspirasi rakyat, jika rakyat yang dekat dengan pemerintahan maka akan ada peluang untuk memperjuangkan ideologi yang dimiliki agar tercapainya tujuan organisasi. Sedangkan yang berkuasa di setiap periode berbeda-beda. Informan pengamat politik mengatakan bahwa sast ini yang mendominasi pemerintahan adalah NU (Nadhatul Ulama). Akan lebih mudah menentukan Otoritas Agama dengan melihat siapa yang menduduki jabatan sebagai Menteri Agama Republik Indonesia pada saat terbentuknya wacana. Tahun 2010 adalah masa jabatan Presiden Susilo Bambang Yudhoyono. Dalam periode tersebut yang menjabat sebagai Menteri Agama yaitu Muhammad Maftuh Basyuni, beliau merupakan mantan sekretaris negara pada periode Gus Dur yang masyarakat Indonesia mengetahui bahwa Gus Dur adalah tokoh besar dari NU (Nadhatul Ulama). Sehingga dapat dilihat jika ada faktor otoritas dalam pemilihan tokoh-tokoh yang menduduki struktural negara.

Menurut Sasson dalam buku (Partria\&Arief, 2015:154), Gramsci bergerak dalam suatu pandangan tentang Negara sebagai instrumen dari sebuah klas. Negara adalah Negara klas yang menciptakan kondisi-kondisi yang di bawah klas tertentu dapat berkembang secara penuh, namun ia bertindak atas nama kepentingan universal dalam sebuah lapangan yang secara konstan merubah equilibrium antara klas dominan dan klas pinggiran. Sehingga melalui tokohtokoh yang maju ke pemerintahan maka mereka dapat membawa dan membantu institusiatauorganisasiyang mendukungnya. Sehingga tidak heran jika seorang politikus membawa kepentingan organisasi dalam membantu tujuan organisasi melalui 
pemerintahan.

Dari semua itu disampaikan melalui media. Hubungan antara politik dan media massa sangat erat. Karena tanpa media maka informasi dan tujuan politik tidak bisa menyebar ke dalam jangkauan yang lebih besar. Tetapi dalam hal ini kasusnya adalah media di Indonesia sudah tidak netral dan khususnya di setiap stasiun TV ada pemilikpemiliknya, dan pemilik tersebut rata-rata menduduki jabatan di pemerintahan. Banyak juga TV nasional milik pemerintah sehingga dalam penyampaian kepada masyarakat lebih mudah dan pemerintah dapat menghendaki berita apa saja yang akan ditayangkan. Siapa yang dominan dan menang akan unggul dan memenangkan dalam pembentukan opini publik.

Menurut jurnal kajian komunikasi Erfina Nurussa'adah (2017: 44), ia mengatakan bahwa kehidupan partai politik di Indonesia cenderung mengedepankan kepentingan politik praktis dan mengesampingkan nilai ideologi. Pergeseran nilai ideologi dalam partai politik bukan sesuatu yang baru. Demi kepentingan kekuasaan, partai politik akan berlomba-lomba membuka diri untuk dapat mewadahi semua basis pemilih. Kondisi ini menjadikan ideologi partai tidak lagi menjadi unsur utama dalam pembuatan keputusan internal partai, selain itu ideologi tidak lagi menjadi tolak ukur dalam menyusun kebijakan. Sehingga kebijakan yang dianggap adil belum tentu adil bagi keseluruhan, akan tetapi bagi kepentingan suatu kelompok saja. Selanjutnya kekuasaan juga dipengaruhi oleh faktor budaya.

Gramsci berpendapat bahwa media merupakan sebuah alat hegemoni seperti media termasuk kesatuan dalam perang dimana terjadinya perjuangan aktif dalam memperebutkan hegemoni. Gramsci juga tidak melihat media sebagai alat yang pasif, tetapi secara total bersama media tandingan membentuk sebuah ruang, sebuah perang bahasa atau perang simbol dalam rangka memperebutkan penerimaan publik atau gagasan-gagasan ideologis. Tepat yang dikatakatan informan pengamat politik bahwa siapa yang dominan maka dia yang akan mendapatkan posisi dalam pembentuk opini publik.

Media memang sangat mempunyai pengaruh yang besar terhadap pembentukan opini dan persepsi publik. Muhammadiyah sebagai organisasi Islam menggunakan caranya untuk menyebarkan dan memberikan wawasan tentang pemikiranpemikiran yang dimiliki oleh KH. Ahmad Dahlan yang sekarang membentuk sebuah organisasi bernama Muhammadiyah. Media yang digunakan untuk pembentukan wacana adalah film. Dengan menggunakan film, maka masyarakat luas dapat memperoleh ilmu dari film tersebut. Adanya film tidak luput hubungannya dengan pembuat wacana yaitu Hanung Bramantyo.

Jika dihubungkan teori film sebagai komunikasi massa. Menurut Bittner (dalam Suryanto, 2015:144) Komunikasi massa adalah pesan yang dikomunikasikan melalui media massa, yaitu surat kabar, radio, televisi, internet, majalah dan sebagainya. Sehingga pesan yang disampaikan disini adalah konten tentang perjuangan tokoh KH. Ahmad Dahlan dengan organisasi Muhammadiyahnya, yang disampaikan melalui media massa yaitu film yang dibuat oleh Hanung Bramantyo yang berjudul Sang Pencerah. Selain dia memberikan sedikit ideologinya kedalam film-filmnya.

Idealisme dan pemikiran-pemikiran pembuat wacana juga mempengaruhi hasil produksi wacana. Selain perwakilan idealisme beliau, Hanung Bramantyo juga tercatat mempunyai riwayat pernah sekolah di Muhammadiyah dan dia hidup di lingkungan Kaumanyang artinya dia tahu dan paham akan kondisi yang terjadi pada saat itu. Dia juga ikut merasakan kekhawatiran seperti yang ia katakan dalam wawancara tersebut. Dari hasil wawancara dengan Adhitya Mahasiswa Ikatan Muhammadiyah Kabupaten Bandung mengatakan bahwa

Tujuan membuat film ini tidak hanya dari segi komersil tetapi niat dalam diri untuk mengedukasi masyarakat bahwa ada tokoh pahlawan Nasional yang bernama KH. Ahmad Dahlan. Jika ditinjau dari hasil wawancara dari segi pengamat politik, pesan- 
pesan yang disampaikan dalam film tersebut sangat jelas yaitu tentang toleransi antar sesama agama, dominansi dan menurutnya film ini banyak cerita bagaimana $\mathrm{KH}$. Ahmad Dahlan memakai intelektualnya kecerdasannya itu untuk mematahkanlawanlawanya dalam tanda petik. Lawan-lawan tersebut yaitu pemuka-pemuka agama atau Otoritas Agama. Film ini menurut beliau, sangat ada relevansinya jika dihubungkan dengan jaman sekarang contohnya penyebutan "kafir". Orang sangat mudah sekali mengatakan "kafir" kepada seseorang yang berbeda paham dengan kelompoknya. Sehingga motif dan faktor sutradara dalam membuat film dalam pandangan informan pengamat film, bahwa kekhawatiran Hanung Bramantyo terhadap bangsa Indonesia ini selalu tercurahkan kepada film-film yang diproduksinya. Menurut hasil wawancara dengan pengamat film, ia mengatakan bahwa adanya kegelisahan dari sosok hanung soal beragama di negara Indonesia khususnya masalah kebhinekaan. Terlihat dari film-film yang dikeluarkan salah satunya "Cinta tapi Beda" dan "Tanda Tanya". Ia memperlihatkan bahwa kebhinekaan tidak hanya antar agama tetapi juga sesama agama itu sendiri. Selain itu yang ingin ditunjukkan oleh pembuat wacana adalah bagaimana seorang umat Islam dalam memaknai agamanya sendiri. Malah yang terjadi di masyarakat Islam di Indonesia, adanya hierarki dalam beragama. Ada satu tokoh yang dijadikan panutan sehingga terkesan mendewakan tokoh tersebut, seakan-akan tokoh tersebut menjadi satu-satunya yang paling benar dan titisan Tuhan yang perlu kita turuti. Makna ke-Tuhanan disini sudah bergeser. Agama adalah bagaimana manusia berkomunikasi dengan Tuhan sesuai dengan koneksi batin yang langsung kepada Tuhan, bukan melalui tokoh-tokoh, Pemuka Agama yang diatas peneliti sebut sebagai Otoritas Agama. Muhammadiyah dalam sejarahnya mengatakan bahwa sebenarnya dalam pendidikan ia juga ingin mengubah sistem hierarki kedalam bentuk egaliter. Sehingga tidak ada tingkatan dalam pendidikan, murid tidak serta merta menerima apa yang dikatakan oleh seorang guru. Tetapi ia juga harus bersikap kritis dan mengerti atau paham akan makna yang sebenarnya disampaikan oleh seorang "Kyai” atau Guru.

Menurut informan pengamat film, dalam film tersebut memperlihatkan bahwa Agama yang sebenarnya adalah sebuah medium dimana manusia bisa lebih mendekatkan diri kepada Tuhan. Tetapi pada kenyataannya dalam film tersebut, Hanung juga menggambarkan dalam film bahwa persoalan agama malah dibuat rumit hanya masalah ritus, atau agama sebagai institusi saja, sebagai medium untuk Otoritas Agama yang ingin menguasai sebuah perkumpulan. Sehingga makna agama itu sendiri tidak sampai kepada Tuhan tetapi berhenti pada urusan duniawi saja. Sehingga teori Gramsci tentang hegemoni sangat terlihat dengan jelas dalam film ini. Hegemoni melalui institusi atau klas-klas untuk memperoleh suatu kekuasaan dalam negara.

Gramsci juga mengatakan bahwa ada dua jenis intelektual dalam hegemoni, khususnya di dalam bidang pendidikan. Yaitu intelektual tradisional dan intelektual organik. Intelektual tradisional lebih terlihat independen, otonom, serta menjauhkan diri dari kehidupan masyarakat. Mereka hanya mengamati serta mempelajari kehidupan masyarakat dari kejauhan dan seringkali bersifat konservatif (anti terhadap perubahan) seperti para penulis sejarah, filsuf dan para profesor. Kedua adalah intelektual organik. Mereka adalah yang sebenarnya menanamkan ide, menjadi bagian dari penyebaran ide-ide yang ada di masyarakat dari kelas yang berkuasa, serta turut aktif dalam pembentukan masyarakat yang diinginkan. Jika dihubungkan dengan teks film Sang Pencerah, maka bentuk atau cara counter hegemoni yang tampak yaitu intelektual organik. Dibuktikan dengan adanya penerapan dan praktik langsung KH. Ahmad Dahlan beserta muridnya untuk membuat sekolah, mengajak anak-anak Kauman untuk belajar bersama di langgar dan juga menyantuni anak yatim dan orang miskin di sekitar Kauman.

Dari ketiga tahap yang peneliti lakukan yaitu mikrostruktrural, mesostruktural dan 
makrostruktural. Ada beberapa hal yang dapat disimpulkan sebagai penekanan pada pesan yang disampaikan. Pertama, tentang pendidikan, merupakan bentuk media yang digunakan dalam menyebarkan dan medium adanya counter hegemoni atau hegemoni tandingan untuk melawan kelas dominan yaitu Otoritas Agama. Pendidikan yang ditunjukkan dalam teks dapat membuat renungan bagi pemerintah dan masyarakat Indonesia. Dalam teks dialog, pendidikan diajarkan bagaimana seorang murid berlatih untuk kritis dan memulai segala sesuatunya untuk bertanya. Jadi bukan guru yang memberikan penanaman sesuatu kepada anak, dengan seperti itu akan adanya persepsi murid-murid yang mengatakan bahwa semua perkataan guru adalah benar. Maka dari itu kebiasaan masyarakat Indonesia akan lebih mudah untuk menerima segala sesuatu yang hanya sebatas di permukaan saja tanpa adanya rasa keingin-tahuan terhadap kebenaran yang sesungguhnya.

Jika dihubungkan dengan teori Gramsci, ia menyatakan bahwa hegemoni dapat terjadi melalui media massa, sekolah-sekolah, bahkan melalui khotbah atau dakwah kaum religius, yang melakukan indoktrinasi sehingga menimbulkan kesadaran baru bagi kaum buruh. Ia juga menyatakan bahwa solusi untuk melawan hegemoni (Counter hegemoni) dengan menitikberatkan pada sektor pendidikan. Sehingga dalam hal ini, sudah terlihat jelas bahwa KH. Ahmad Dahlan hadir dan melakukan kegiatannya di bidang pendidikan, dakwah dengan cara membuat langgar, dan mengikuti perkumpulan Budi Utomo untuk mendukung gerakannya dalam meng-counter hegemoni yang ada yaitu pemikiran-pemikiran yang masih terpaku pada Otoritas Agama yang ada di Kauman.

Kedua, tentang kekuasaan, merupakan sesuatu yang sebenarnya setiap manusia berniat untuk mempunyai keinginan untuk menguasai. Kekuasaan tidak luput dari media dan media pun tidak luput dari faktor-faktor dukungan institusi dan organisasi. Sehingga produksi, konsumsi wacana tidak serta merta jadi begitu saja dan bersifat netral. Ada banyak hal yang menjadi faktor pendorong keluarnya sebuah wacana dengan tujuan yang baik atau bahkan yang buruk. Bisa dari segi politik yang berkaitan dengan pemerintahan, ideologi, maupun dari kepentingan "lebel-lebel" agama yang mengatas namakan Islam.

\section{SIMPULAN}

Penelitian ini dilakukan untuk mengetahui bentuk counter hegemoni menggunakan Analisis Wacana Kritis Fairclough yaitu mikrostruktural (analisis teks), mesostruktural (praktik wacana) dan makrostruktural (praktik sosiokultural) dalam film Sang Pencerah. Dari penelitian yang dilakukan dapat ditarik kesimpulan.

Pada tahap Mikrostruktural (analisis teks), counter hegemoni ditujukkan oleh adanya kata "kafir" yang selalu disebutkan dalam teks dialog. Hal ini memperlihatkan bahwa adanya ketidakadanya keseimbangan sosial, ada yang minoritas dan dominan. Dimana klasdominanyang mempunyai kuasa yang lebih sehingga berhak mengatakan dan seakan-akan menghukum kepada pihak yang minoritas karena perbedaan paham.

Pada tahap Mesostruktural (praktik wacana), counter hegemoni ditunjukkan oleh adanya perdebatan arah kiblat yang menjadi keributan di tengah-tengah masyarakat. Kritik tentang arah kiblat semakin membuat KH. Ahmad Dahlan dijuluki sebagai "Kyai Kafir" dan terasingkan di lingkungannya. Kasus arah kiblat muncul kembali dengan berita MUI menetapkan perubahan arah kiblat pada tahun 2010.

Pada tahap Makrostruktural (praktik sosiokultural), menunjukkan bahwa idealisme pembuat wacana masuk ke dalam media (film), kondisi sosial yang mendukung adanya wacana yaitu karena adanya pergeseran makna Islam yang dipahami masyarakat, institusi maupun organisasi seperti pemerintah mempengaruhi terbentuknya wacana yang ingin dikehendaki kelas dominan agar membentuk opini publik yang diinginkan penguasa. Sehingga media ikut serta membentuk sebuah counter. 


\section{DAFTAR PUSTAKA}

Achmad, Nur \& Tanthowi, Pramono, U. (2000) Muhammadiyah “D ig u g a t”. Jakarta: Kompas

Bungin, Burhan (2007). Penelitian Kualitatif Edisi Kedua, Jakarta: Prenada Media Group

Fairclough, H. (1989). Language and Power. London: Longman

Fairclough, Norman Critical Discourse The Critical Study (2010). Language, United $\mathrm{K}$ i n g d o m : Pearson Education Group.

Gramsci, A (1971) Selections from the Prison Notebooks, London: Lawrence and Wishart.

Herawati, Maemun (2016). P e m a k n a a n Gender Perempuan Pekerja Media di Jawa Barat. Jurnal Kajian Komunikasi 4(1),84-94.

Heryanto, Ariel. (2015). Identitas d a $n$ Kenikmatan Politik Buda ya Layar Indonesia. Jakarta: KPG

Lestari,Sri. Fatwa MUI tentang arah kiblat. (Akses:11 September 2017, 18.30 WIB) dari ( http: / / w ww. bbc.com/indones i a / b e r i t a indonesia/2010/07/1 o0720_kabah)

Moleong, Lexy J. (2007). M e t o d o l o g i Penelitian $\mathrm{K} \mathrm{u}$ a $\mathrm{l}$ i $\mathrm{t}$ a $\mathrm{t}$ i f. Bandung:Penerbit PT Remaja Rosdakarya

Moleong, Lexy J. (2012). Metode Penelitian Kualitatif. Bandung: PT Remaja Rosdakarya

Mulyana, Deddy.

(2007). Pengantar Ilmu Komunikasi. Bandung: Rosdakarya

Negara dan kekerasan agama. (Akses: 11 Januari 2017, pukul 18.40 WIB) dari (http://www.bbc.com/indonesia/ laporan_khusus/2012/07/120702_ peran_negara_toleransi,)

Nurussa'adah, E. \& Sumartias, S. (2017). Komunikasi Politik Partai Keadilan Sejahtera (PKS)dalam Keterbukaan Ideologi. Jurnal Kajian Komunikasi 5(1), 43-52.

Negara dan kekerasan agama. (Akses: 11 Januari 2017, pukul 18.40 WIB) dari (http://www.bbc.com/indonesia/ laporan_khusus/2012/07/120702_ peran_negara_toleransi,)

Patria, N. \& Arief, A. (2015). Antonio Gramsci Negara \& Hegemoni. Yogyakarta: Pustaka Pelajar

Pendataan anak jalanan tidak cukup.(Akses :12 Januari 2018, pukul 15.12 WIB) dari (http://www.bbc.com/indonesia/ majalah/2010/01/100121_streetkids_ storyana),

Rais, Amin. (1997). Visi dan Misi Muhammadiyah, Yogyakarta: Pustaka Suara Muhammadiyah

Samsuri. (1994). Analisis Bahasa. Jakarta: Erlangga

Sardiman. (2000). Masyarakat Madani Muhammadiyah dan Politik. J u $r$ n a $l$ Informasi XXXVIII (1) Storey, J (2009) Cultural Theory and Popular Culture Fifth Adition, London: Pearson

Sugiyono. (2009). Metode Penelitian Kuantitatif, Kualitatif dan R\&D. Bandung : Alfabeta

Suryanto. (2015). Pengantar Ilmu

Komunikasi. Bandung: Pustaka Setia.

Roger, Simon. (2004). Gagasan Politik Gramsci. Yogyakarta: Pu s taka Pelajar

100 tahun Muhammadiyah Menyinari Negeri. (2010). Yogyakarta: Majelis Pustaka dan Informasi Pimpinan Pusat Muhammadiyah 